\title{
Adsorptive/desorptive potential of cationic basic yellow 28 (by28) dyes onto natural untreated clay from aqueous phase
}

\begin{abstract}
The adsorption of basic dye "C.I. basic yellow 28" (BY28) onto Tunisian smectite-rich clay in aqueous solution was studied in a batch system. Tunisian raw clay sampled in Jebel Romana (meridional Atlas of Tunisia) composed mainly of smectite (52\%) has shown efficiency for removal of BY28 from aqueous solutions. The results showed that basic $\mathrm{pH}$ is favorable for the adsorption of dye and adsorption. Adsorption isotherm was described by both Freundlich and Langmuir models. The maximum monolayer adsorption capacity was found to be $76.92 \mathrm{mg} / \mathrm{g}$ at $25^{\circ} \mathrm{C}$ (at room temperature). Adsorption kinetics was studied and modeled. The maximum BY28 desorbed percentage was $17 \%$ and it was obtained for strong acidic conditions ( $\mathrm{pH}$ 2). Smectitic clay showed to be an advantageous adsorbent in terms of price and versatility, being effective under a wide $\mathrm{pH}$ range, for cationic dye. Its use as adsorbent does not require further purification or chemical modifications, which is beneficial for the environment and for the economy of the treatment.
\end{abstract}

Volume 2 Issue I - 2018

\author{
Chaari Islem,' Cherbib Afef,' Fakher \\ Jamoussi, ${ }^{2}$ Medhioub Mounir, ${ }^{3}$ Mnif Adel' \\ 'Useful Materials Valorization Laboratory, National Center for \\ Research in Materials Sciences, Tunisia \\ ${ }^{2}$ Laboratoire de Georessources, CERTE, Tunisia \\ ${ }^{3}$ Département des Sciences de la Terre, Faculté des Sciences de \\ Sfax, Tunisia
}

Correspondence: Chaari Islem, Maître Assistante, National Center for Research in Materials Sciences, Tunisia,

Email chaari_islem@yahoo.fr

Received: September 06, 2017 | Published: February 21, 2018

Keywords: adsorption, smectitic clay, textile dye, equilibrium, kinetics, desorption

Abbreviations: FTIR, fourier-transform infrared; X-RD, $\mathrm{X}$-ray diffraction; BY28, dye-basic yellow 28; MB, methylene blue; CEC, cation exchange capacity

\section{Introduction}

Textile industries are one of the largest consumers of water and hence producers of liquid effluents. The dyeing and finishing processes generate volumes of wastewaters in the range 45-450 $\mathrm{m}^{3}$ per ton of product, ${ }^{1}$ containing salts, acids, bases, additives and unfixed dyes. A suitable treatment of these complex wastewaters should lead to a strong decline on the organic load, and desirably to a complete elimination of the residual color. There are several types of commercial dyes, ${ }^{2,3}$ and some of these dyes posses a high resistance to biodegradation and persist a long time in the environment. ${ }^{4}$ These compounds and their degradation by products are generally believed to be carcinogenic or toxic and become harmful to humans or to the environment. Adsorption processes have been proposed as a fast alternative to remove contaminants from water. Several natural low cost adsorbents have been tested to remove synthetic dyes. ${ }^{5}$ In particular, smectite clays have been broadly studied as adsorbents of cationic dyes. This type of clay has a layered structure where each layer is composed by tetrahedral silicate units fused into an edgeshared octahedral plane of aluminum. The isomorphic substitution of $\mathrm{Al}^{3+}$ for $\mathrm{Fe}^{2+}$ or $\mathrm{Mg}^{2+}$ and $\mathrm{Si}^{4+}$ for $\mathrm{Al}^{3+}$ generates charge deficiencies on the surface and interlayer space.

The intrinsic negative charge is compensated with inorganic captions in the interlayer that can be exchanged by other inorganic or organic captions, being suitable for adsorption of cationic synthetic dyes. The aim of the present work was to investigate the efficiency of AR towards the adsorption of Basic Yellow 28 from aqueous solution. This work describes the feasibility of removal of a cationic dye-Basic Yellow 28 (BY28) from aqueous solutions by using raw clay as a new low cost adsorbent. The clay was characterized using methylene blue adsorption for determination of total specific surface area, cation exchange capacity, point of zero charge, Fouriertransform infrared (FTIR) and X-ray diffraction (XRD). Adsorption experiments were achieved out as a function of $\mathrm{pH}$, contact time, initial dye concentration, adsorbent dose and temperature. Kinetics, thermodynamic, isotherms and mass transfer mechanisms have also been discussed for the adsorption of BY28 from aqueous solutions.

\section{Experimental}

\section{Adsorbent}

The BY28 was obtained from textile industry (Tunisia) with $99.99 \%$ purity. The dye solutions used in the experiments $(1000$ $\mathrm{mg} / \mathrm{L}$ ) were prepared by dissolving the required amount of dye in distilled water. The characteristics and chemical structure of BY28 are (Table 1).

Table I Basic properties of the investigated dye

\begin{tabular}{ll}
\hline Cl name & Cl basic yellow 28 \\
\hline Commercial name & Maxilon Golden Yellow GL 200\% \\
Chemical formula & $\mathrm{C}_{21} \mathrm{H}_{27} \mathrm{~N}_{3} \mathrm{O}_{5} \mathrm{~S}$ \\
Class & $\mathrm{Azo}$ \\
Molecular weight & 433,52 \\
Max. wave length $(\lambda \text { max })^{\mathrm{a}}$ & $440 \mathrm{~nm}$ \\
pH stability & $3-10$ \\
Molecular Structure & \\
\hline
\end{tabular}




\section{Adsorbent and its characterization}

In this study, natural untreated clay (AR) was collected from the meridional Atlas of Tunisia (Figure 1). It was sampled in Jebel Romana in El Hamma area. Then, it was crushed, ground, and sieved through a $63 \mu \mathrm{m}$ sieve and samples were collected from under the sieve and dried at $70{ }^{\circ} \mathrm{C}$ in an oven for $2 \mathrm{~h}$ prior to use. It was used as the adsorbent for the removal of BY28 from aqueous solutions in a batch treatment process. Clay was used without any treatment. Fouriertransform infrared (FTIR) spectra were measured using Perkin-Elmer Spectrum One model FTIR spectrometer. The methylene blue (MB) adsorption method was used in this work to assess the surface area of AR. ${ }^{6}$ Cation exchange capacity (CEC) was estimated using the copper ethylenediamine complex method. ${ }^{7}$ The X-ray diffraction (XRD) patterns were obtained using phillips X'pert diffractometer The zero point charge of the raw $\mathrm{AR}\left(\mathrm{pH}_{\mathrm{pzc}}\right)$ defined as being the $\mathrm{pH}$ for which there is absence of positive or negative charge on the surface of the AR was determined by the method describe by. ${ }^{8}$

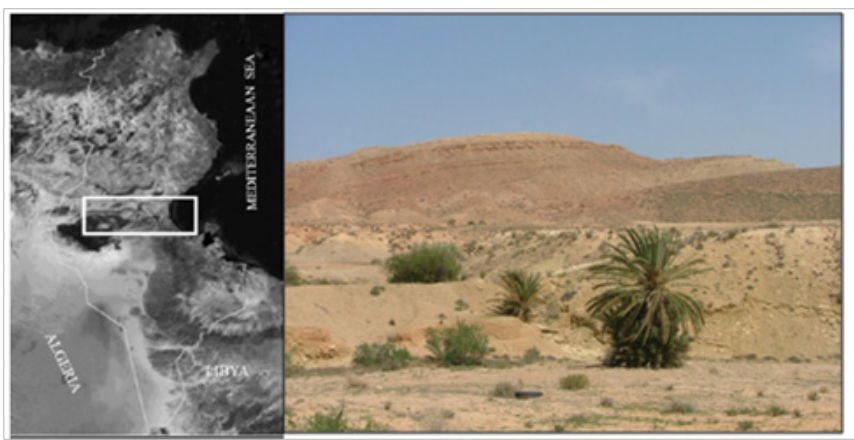

Figure I Localization of the studied clay deposit.

\section{Experimental adsorption isotherms}

Adsorption experiments were evaluated in batch equilibrium mode. Sample clay of the volume $100 \mathrm{~mL}$ were taken after mixing the adsorbent and BY28 solution bearing solution and at predetermined time intervals (1-120 min) for the determination of residual BY28 concentration. $\mathrm{pH}$ was adjusted by the addition of dilute aqueous solutions of $\mathrm{HCI}$ or $\mathrm{NaOH}(0.01 \mathrm{M})$. The initial and equilibrium BY28 concentrations of dye was estimated using Shimadzu-1650UV-Visible spectrophotometer at the wavelength of $440 \mathrm{~nm}$. The kinetics of adsorption was determined by analyzing adsorptive uptake of the dye from the aqueous solution at different time intervals. For adsorption isotherms, dye solutions of different concentrations were agitated with the known amount of adsorbent until the equilibrium was achieved. Various experimental parameters such as $\mathrm{pH}(2-11)$, temperature (25$\left.45^{\circ} \mathrm{C}\right)$, adsorbent mass $(0.1-2 \mathrm{~g} / \mathrm{L})$, initial BY28 concentration (25$300 \mathrm{mg} / \mathrm{L}$ ) and contact time were investigated. The amount of dye removed and the amount of dye adsorbed on per unit of adsorbent $\left(\mathrm{q}_{\mathrm{e}}\right)$ at the sampling time were calculated using the following equations:

$$
\begin{aligned}
& \text { Dye removal } \%=\frac{\left(C_{0}-C_{e}\right)}{C_{0}} \times 100 \rightarrow(1) \\
& q_{e}=V\left(C_{0}-C_{e}\right) / m \rightarrow(2)
\end{aligned}
$$

Where $\mathrm{C}_{0}(\mathrm{mg} / \mathrm{L})$ is the initial concentration of dye, $\mathrm{C}_{\mathrm{e}}(\mathrm{mg} / \mathrm{L})$ is the concentration of dye at equilibrium, $\mathrm{V}(\mathrm{L})$ is the volume of dye solution, and $\mathrm{m}(\mathrm{g})$ is the mass of adsorbent.

\section{Desorption studies}

In the desorption studies, the raw adsorbent that was used for the adsorption of dye solution was separated from solution by centrifugation and then dried. The dried clay loaded with BY28 dye, was shaken $(1.0 \mathrm{~g} / \mathrm{L})$ with solutions at different $\mathrm{pH}$ (range 2-11) using $\mathrm{NaOH}$ and $\mathrm{HCl}$ solutions as eluents. After $5 \mathrm{~h}$ of contact time, the dye concentration in the liquid phase was analyzed and the percentage of the dye desorbed from the AR was calculated according to:

$$
\text { desorption }=\frac{\text { Mass desorbed }}{\text { Mass adsorbed }} \times 100 \rightarrow(3)
$$

\section{Results}

\section{Characterization of AR clay}

The FTIR spectrum of AR sample Figure 2 shows that absorption bands at 3627 and $917 \mathrm{~cm}^{-1}$ are attributable to Al-Al- $\mathrm{OH}^{-}$stretching and bending modes of vibrations. ${ }^{9}$ The band appeared at $1439 \mathrm{~cm}^{-1}$ corresponds to that of carbonate [calcite $\left(\mathrm{CaCO}_{3}\right)$ or dolomite $(\mathrm{Ca}, \mathrm{Mg}$ $\left.\left(\mathrm{CO}_{3}\right)_{2}\right)$ ]. The bands appeared at 537,425 and $474 \mathrm{~cm}^{-1}$ correspond to $\mathrm{Si}-\mathrm{O}-\mathrm{Al}, \mathrm{Si}-\mathrm{O}-\mathrm{Si}$ and $\mathrm{Si}-\mathrm{O}-\mathrm{Mg}$, respectively. The specific surface area and CEC of AR were about $397 \mathrm{~m}^{2} / \mathrm{g}$ and $49.5 \mathrm{meq} / 100 \mathrm{~g}$, respectively. The X-Ray diffraction analysis indicated that the raw AR clay is mainly composed of smectite $(52 \%)$ associated to kaolinite $(6 \%)$, illite $(11 \%)$, quartz $(10 \%)$, calcite $(19 \%)$, and feldspars $(2 \%)$ (Table 2). Results show that $\mathrm{pH}_{\mathrm{zpc}}$ of AR clay was 8.9 (Figure 3 ).

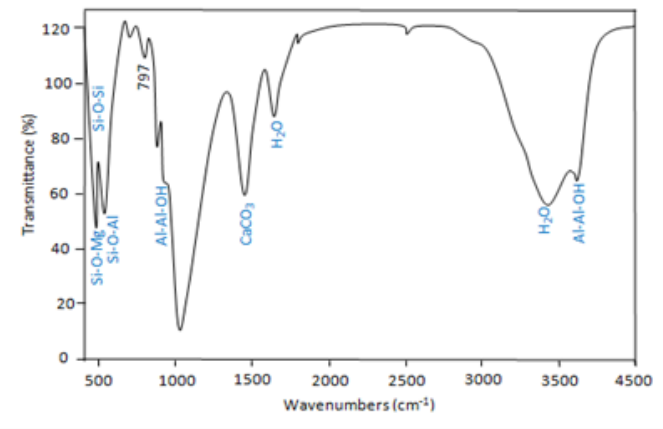

Figure 2 FTIR of AR.

Table 2 Mineralogical analysis of AR

\begin{tabular}{lllllll}
\multirow{2}{*}{ Sample } & \multicolumn{3}{l}{ Total rock mineralogy (\%) } \\
\cline { 2 - 7 } & \multicolumn{2}{l}{ Clay minerals } & & \multicolumn{4}{l}{ Non clay minerals } \\
\hline \multirow{4}{*}{ AR } & Smectite & Illite & Kaolinite & Quartz & Calcite & Feldspars \\
& $(\mathrm{S})$ & (I) & (K) & (Q) & (C) & $($ F) \\
& 52 & II & 6 & 10 & 19 & 2 \\
\hline
\end{tabular}

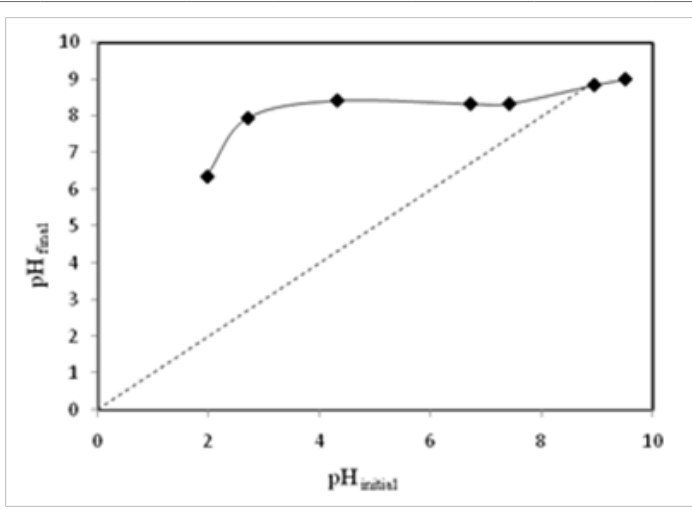

Figure $3 \mathrm{pH}_{\mathrm{ZPC}}$ of $\mathrm{AR}$. 


\section{Effect of solution $\mathrm{pH}$ on adsorbate adsorption}

The effect of $\mathrm{pH}$ on adsorption of BY28 onto AR was studied in the range of 2-11 which is presented in Figure 4. It was found that the removal efficiency of dye increased from $73.23 \%$ to $99.5 \%$ due to change in $\mathrm{pH}$ from 2 to 11 for a fixed initial dye concentration of $50 \mathrm{mg} \mathrm{L}^{-1}$ at equilibrium. However, $\mathrm{pH} 11$ appears an optimal level due to high adsorption efficiency $(99.5 \%)$. Clay minerals comprises of various functional groups such as aluminol and silanol groups which are affected by the $\mathrm{pH}$ of the solution. The point of zero charge, $\mathrm{pH}_{\mathrm{PZC}}$ of clay particles in aqueous solution is 8.9. The predominant charges on the $\mathrm{AR}$ at acidic $\mathrm{pH}$ are positive and because of cationic dye species, it seems that the dominant mechanism of the adsorption is electrostatic repulsion. With the increasing $\mathrm{pH}$ values, the adsorption of BY28 on clay tends to increase, which can be explained by the increasing electrostatic attraction between the cationic dye adsorbate species and negatively charged adsorbent surfaces. Also lower adsorption at acidic $\mathrm{pH}$ due to the presence of excess $\mathrm{H}^{+}$ions destabilizing cationic dye and competing with the dye captions for the adsorption sites.

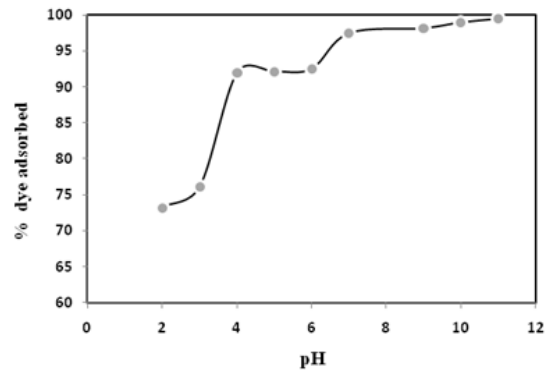

Figure 4 Effect of initial solution $\mathrm{pH}$ on the adsorption of BY28 onto AR.

\section{Effect of contact time}

From Figure 5, it can be seen that adsorption of BY28 on the clay appears to be rapid during the initial phase of the contact time due to the fact that a large number of surfaces are available for adsorption. It then gradually slows down until it reaches equilibrium at $120 \mathrm{~min}$ with an adsorption rate of $92 \%$. During this phase, the surface of the solid becomes saturated.

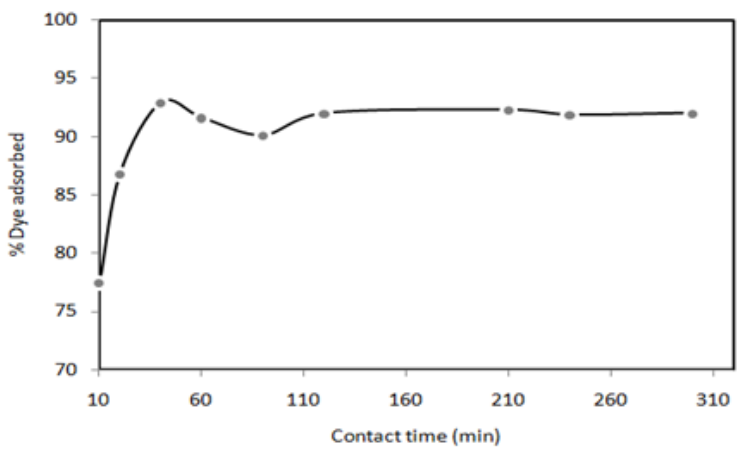

Figure 5 Effect of contact time on the adsorption of BY28 onto AR.

\section{Effect of adsorbent dose}

Initial adsorbent dose requires proper selection because it controls adsorption via available surface area and binding sites. ${ }^{10}$ The results revealed that adsorption efficiency decreased from 96 to $76 \%$ (Figure not shown here). This behavior is ascribed to a decrease in adsorption surface area and the number of active sites for adsorption.

\section{Effect of initial dye concentration}

To evaluate the effect of dye initial concentration adsorption, 20$150 \mathrm{mg} / \mathrm{L}$ concentration range was shown in Figure 6. By increasing initial dye concentration, the percentage removal increased from 20 to $80 \mathrm{mg} / \mathrm{L}$ then decreases. At lower initial dye concentration, the adsorption sites were available for dye adsorption. At higher concentration, however the available sites might occupied and subsequently, the dye removal depends on the initial concentration.

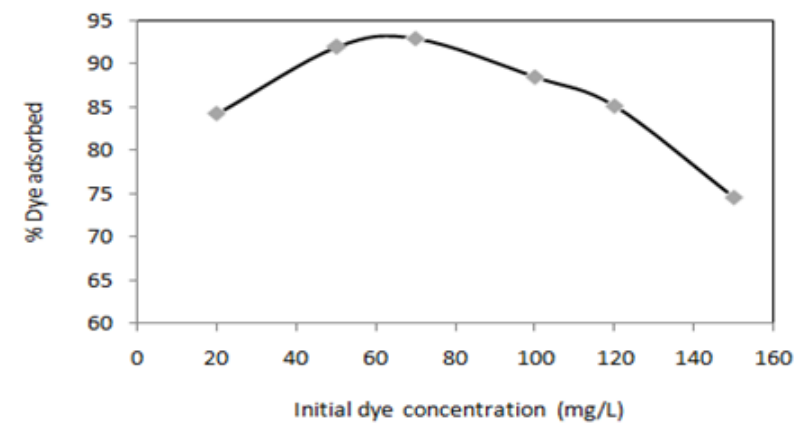

Figure 6 Effect of initial dye concentration on the adsorption of BY28 onto AR.

Equilibrium modelling: In our present study two different adsorption isotherms, Langmuir and Freundlich have been used to fit the experimental adsorption data.

Langmuir isotherm: The Langmuir equation is probably the best known and most widely applied adsorption isotherm and is based on the assumption that adsorption takes place on homogeneous surface. It is represented as follows: ${ }^{11}$

$$
q_{e}=\frac{q_{m} b C_{e}}{1+b C_{e}} \rightarrow(4)
$$

A linear form of this expression is

$$
\frac{C_{e}}{q_{e}}=\frac{1}{q_{m} b}+\frac{C_{e}}{q_{m}} \rightarrow(5)
$$

Where $\mathrm{C}_{\mathrm{e}}$ is the equilibrium concentration of BY28 in solution $(\mathrm{mg} / \mathrm{L}), \mathrm{q}_{\mathrm{e}}$ is the adsorption capacity of the adsorbent at equilibrium $(\mathrm{mg} / \mathrm{g}), \mathrm{q}_{\mathrm{m}}$ is the maximum adsorption capacity of the adsorbent $(\mathrm{mg} / \mathrm{g}), \mathrm{b}$ is the Langmuir equilibrium constant related to the affinity of binding sites $(\mathrm{L} / \mathrm{mg})$. The essential characteristic of the Langmuir isotherm can be expressed in terms of a dimensionless constant separation factor (Eq. (6)).

$$
R_{L}=\frac{1}{1+C_{0} b} \rightarrow(6)
$$

Where $\mathrm{C}_{0}$ is the initial concentration of sorbet $(\mathrm{mg} / \mathrm{L})$ and the $R_{L}$ value indicates the unfavorable $\left(R_{L}>1\right)$, linear $\left(R_{L}=1\right)$, favorable $\left(0<\mathrm{R}_{\mathrm{L}}<1\right)$ or irreversible $\left(\mathrm{R}_{\mathrm{L}}=0\right)$ nature of adsorption process. Value of $R_{L}$ for adsorption of BY28 is 0.14 , which reveal the adsorption behavior of dye onto AR was favorable with $R_{L}$ value less than 1 .

\section{Freundlich isotherm}

The Freundlich isotherm is expressed by the following empirical equation (Freundlich 1906): 


$$
q_{e}=K_{F} C_{e}^{1 / n} \rightarrow(7)
$$

Where $\mathrm{K}_{\mathrm{F}}(\mathrm{mg} / \mathrm{g})$ and $1 / \mathrm{n}$ are characteristic constants representing the adsorption capacity and adsorption intensity of the system respectively. The equation may be liberalized by taking the logarithm on both sides:

$$
\ln q_{e}=\ln K_{F}+\frac{1}{n} \ln C_{e} \rightarrow(8)
$$

The isotherm constants for the isotherms studied and the correlation coefficient, $\mathrm{R}^{2}$ with the experimental data are listed in Table 3 . Based on the $\mathrm{R}^{2}$ values, the adsorption of dye by clay fitted the two models. The maximum amount of adsorption of Basic Yellow 28 onto Romana clay was about of $76.92 \mathrm{mg} / \mathrm{g}$ (Table 3) which is close to that found during the adsorption of methylene blue onto kaolinite-smectite rich clay where $\mathrm{q}_{\mathrm{m}}$ value was $65.1 \mathrm{mg} / \mathrm{g} .{ }^{12}$ While it is very important to that found during the adsorption of Methyl Orange by untreated clay collected from the region of Maghnia (Algeria) where the adsorption capacity was $35 \mathrm{mg} / \mathrm{g}$. ${ }^{13}$ Similarly, it is very important to that found during the adsorption of ethyl violet on kaolinite where the adsorption capacity was $30.911 \mathrm{mg} / \mathrm{g}$.

Table 3 Langmuir and freundlich isotherm constants

\begin{tabular}{lllllll}
\hline Langmuir & & \multicolumn{5}{c}{ Freundlich } \\
\hline qm (mg/g) & b (L/mg) & $\mathbf{R}_{\mathrm{L}}$ & $\mathbf{R}^{2}$ & $\mathbf{K F}$ & $\mathbf{n}$ & $\mathbf{R}^{\mathbf{2}}$ \\
\hline 76.92 & 0.119 & 0.14 & 0.996 & 2.863 & $\mathrm{I} .773$ & 0.981 \\
\hline
\end{tabular}

\section{Adsorption kinetics}

In order to determine the rate constants, pseudo-first order, pseudosecond order and intra-particle diffusion were employed to model the adsorption data during adsorption process (Table 4).

\begin{tabular}{|c|c|c|}
\hline Model type & Parameters & Values \\
\hline \multirow{4}{*}{ Pseudo-I $\left.\right|^{\text {st }}$ ord } & $k_{1}\left(\min ^{-1}\right)$ & 0.032 \\
\hline & $\mathrm{q}_{\mathrm{e}}($ calc. $)(\mathrm{mg} / \mathrm{g})$ & 1.72 \\
\hline & $\mathrm{q}_{\mathrm{e}}(\exp )(\mathrm{mg} / \mathrm{g})$ & 15.33 \\
\hline & $\mathrm{R}_{2}$ & 0.9 \\
\hline \multirow{4}{*}{ Pseudo-2 ${ }^{\text {nd }}$ or } & $\mathrm{K}_{2}\left(\min ^{-1}\right)$ & 0.035 \\
\hline & $\mathrm{q}_{\mathrm{e}}($ calc.) (mg/g) & 15.62 \\
\hline & $\mathrm{q}_{\mathrm{e}}(\exp ).(\mathrm{mg} / \mathrm{g})$ & 15.33 \\
\hline & $\mathrm{R}_{2}$ & 0.99 \\
\hline \multirow{4}{*}{ Intra-particle } & $\mathrm{K}_{\text {difl }}(\mathrm{mg} / \mathrm{g} \min 0.5)$ & 0.48 \\
\hline & $R \frac{1}{2}$ & 0.95 \\
\hline & $\mathrm{K}_{\mathrm{dif2}}(\mathrm{mg} / \mathrm{g} \min 0.5)$ & 0.005 \\
\hline & $R \frac{2}{2}$ & 0.94 \\
\hline
\end{tabular}

Table 4 Kinetic parameters for the adsorption of BY28 onto AR
Pseudo-first-order kinetic model: Lagergren showed that the rate of adsorption of solute on the adsorbent is based on the adsorption capacity and followed pseudo-first-order kinetics as given by the Eq. (9): ${ }^{14}$

$$
\ln \left(q_{e}-q_{t}\right)=\ln q_{e}-k_{1} t \rightarrow(9)
$$

Where $\mathrm{q}_{\mathrm{e}}$ and $\mathrm{q}_{\mathrm{t}}$ are the amounts of adsorbate adsorbed $(\mathrm{mg} / \mathrm{g})$ at equilibrium and at contact time $\mathrm{t}(\mathrm{min})$ respectively, and $\mathrm{k}_{1}$ is the pseudo-first-order rate constant $(1 / \mathrm{min})$. Experimental $\left(\mathrm{q}_{\mathrm{e}, \mathrm{exp}}\right)$ and calculated $\left(\mathrm{q}_{\mathrm{e}, \mathrm{cal}}\right)$ values and coefficients related to Lagergren's plots are given in Table 4. As it can be seen from the results that the experimental $\mathrm{q}_{\mathrm{e}}$ values do not agree with the calculated ones, obtained from the linear plots. Therefore, results suggest that the adsorption of BY28 onto AR is not a pseudo-first-order kinetic adsorption model.

Pseudo-second-order kinetic model: The pseudo-second-order kinetic model used in this study can be represented by the following Eq (10): ${ }^{15}$

$$
\frac{t}{q_{t}}=\frac{1}{k_{2} q_{e}{ }^{2}}+\frac{1}{q_{e}} t \rightarrow(10)
$$

Where $\mathrm{k}_{2}$ is the pseudo-second-order rate constant $(\mathrm{mg} / \mathrm{g} \mathrm{min})$. Table 4 shows a good agreement between the experimental $\left(\mathrm{q}_{\mathrm{e} \text { exp }}\right)$ and the calculated $\mathrm{q}_{e}\left(\mathrm{q}_{e, c a l}\right)$ values. Also, the $\mathrm{R}^{2}$ value obtained from the pseudo-second-order model was close to unity $\left(\mathrm{R}^{2}>0.99\right)$, indicating that the adsorption of BY28 on AR fitted well to this model.

\section{Weber and morris model-intra-particle diffusion model}

This model is usually used to determine the rate-limiting step. The main assomption of the intra-particle diffusion model is that film diffusion is negligible and intra-particle diffusion is the only ratecontrolling step. The non-linear form of the intra-particle diffusion model is expressed as follows ${ }^{16}$ (Table 5):

$$
q_{t}=k_{i d} t^{1 / 2}+C \rightarrow(11)
$$

where $\mathrm{q}_{\mathrm{t}}$ is the amount adsorbed at time $\mathrm{t}$ and $\mathrm{t}^{0.5}$ is the square root of the time and $\mathrm{K}_{\mathrm{id}}\left(\mathrm{mg} / \mathrm{g} \mathrm{min}{ }^{0.5}\right)$ is the rate constant of intra-particle diffusion. Figure 7 shows that the adsorption plots are not linear over the whole time range and can be separated into two linear regions which confirm the multi stages of adsorption. This plot represented the two different stages viz. external mass transfer followed by intraparticle diffusion, signified that the dye molecules were transported to the external surface of the clay particle through film diffusion and its rate was very fast. After that, dye molecules were entered into clay particles by intra-particle diffusion through pores. Moreover from Figure 7, our fitting results show that the plot did not pass through the origin $(C \neq 0)$, indicating that film diffusion and intra-particle diffusion occurred simultaneously. Some other mechanisms such as complexation or ion exchange may also control the rate of adsorption.

Table 5 Kinetic parameters for the adsorption of BY28 onto AR

\begin{tabular}{llllll}
\hline Adsorbent & $\begin{array}{l}\Delta \mathbf{H}^{\circ} \\
\left(\mathbf{K} \mathbf{j ~ m o l} \mathbf{~}^{-1}\right)\end{array}$ & $\begin{array}{l}\Delta \mathbf{S}^{\circ} \\
\left(\mathbf{j} \mathbf{K}^{-1} \mathbf{~ m o l}^{-1}\right)\end{array}$ & $-\Delta \mathbf{G}^{\circ}(\mathbf{K j ~ m o l} \mathbf{~ m})$ & \\
\hline & & & $298 \mathrm{~K}$ & $313 \mathrm{~K}$ & $333 \mathrm{~K}$ \\
$\mathrm{AR}$ & -15.68 & $-0.04 \mathrm{I}$ & 3.46 & 2.23 & 1.822 \\
\hline
\end{tabular}




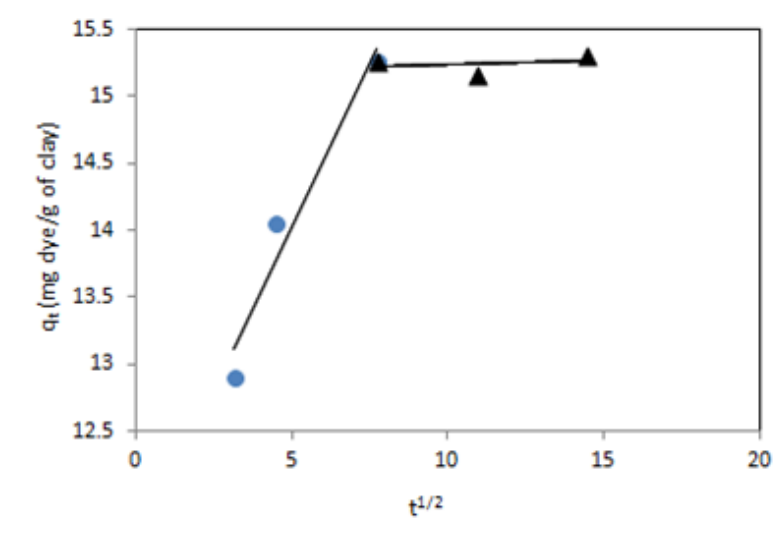

Figure 7 Kinetic plot for the adsorption of BY28 onto AR: Intra-particle diffusion.

\section{Thermodynamic studies}

Thermodynamic parameters, i.e., the enthalpy change, $\Delta \mathrm{H}^{\circ}$, and the entropy change, $\Delta \mathrm{S}^{\circ}$ ads, are obtained by writing the van't Hoff equation in the form:

$$
\operatorname{Ln} \frac{q_{e}}{C_{e}}=-\frac{\Delta H^{\circ}}{2.303 R T}+\frac{\Delta S^{\circ}}{2.303 R} \rightarrow(12)
$$

Where $\mathrm{q}_{\mathrm{e}}$ and $\mathrm{C}_{\mathrm{e}}$ are the adsorption capacity of the adsorbent and the equilibrium dye concentration in solution, respectively. The values of $\Delta \mathrm{H}^{\circ}$ and $\Delta \mathrm{S}^{\circ}$ were determined from the slope and intercept, respectively of the van't Hoff plots $\left[\log \left(\mathrm{q}_{\mathrm{e}} / \mathrm{C}_{\mathrm{e}}\right)\right.$ vs. 1/T] (Figure 8). The Gibbs change in free energy of the adsorption, $\Delta \mathrm{G}^{\circ}$, is calculated using the following equation (Eq. 13):

$$
\Delta G^{\circ}=\Delta H^{\circ}-T \Delta S^{\circ} \rightarrow(13)
$$

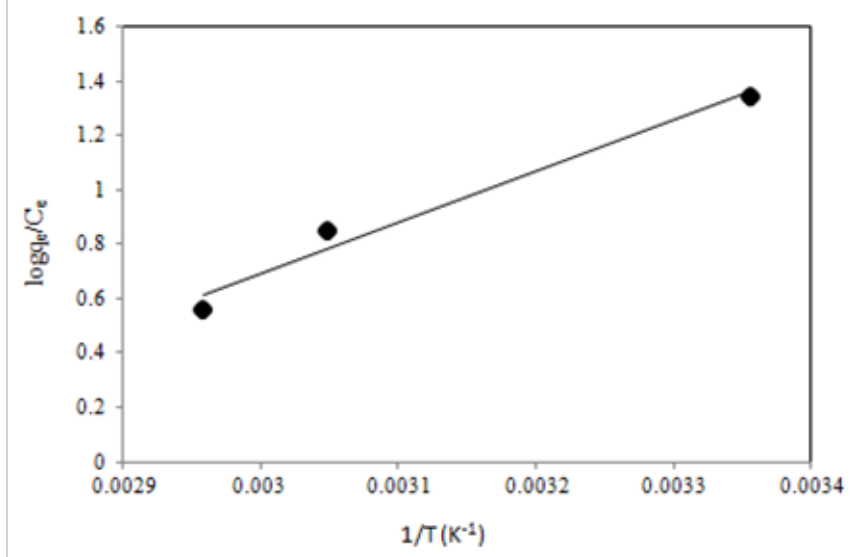

Figure 8 Plot of $\log q_{e} / C_{e} v s ~ I / T$ for values of thermodynamic parameters at different temperatures.

The negative values of $\Delta \mathrm{G}^{\circ}$ and negative value of $\Delta \mathrm{H}^{\circ}$ (Table 6) indicated the spontaneous and exothermic nature of the adsorption. The magnitude of $\Delta \mathrm{H}^{\circ}$ may be used to distinguish between physisorption $(2.1-20.9 \mathrm{~kJ} / \mathrm{mol})$ and chemisorption $(84$ à $420 \mathrm{~kJ} /$ mol). ${ }^{17}$ The $\Delta \mathrm{H}^{\circ}$ value at optimized conditions was $15.68 \mathrm{~kJ} / \mathrm{mol}$. This value is in the range indicative of physisorption. The negative value of entropy change $\left(\Delta \mathrm{S}^{\circ}\right)$ indicated decreased randomness at the solid/ solution interface.

\section{Desorption studies}

Desorption studies were however conducted for BY28-loaded AR, as a function of $\mathrm{pH}$, and results are shown in Figure 9. As it can be seen from Figure 9, that percent desorption decreased with increase in $\mathrm{pH}$ of the aqueous solution. The maximum BY28 desorbed percentage was $17 \%$ and it was obtained for strong acidic conditions $(\mathrm{pH} 2)$. This is just opposite to the $\mathrm{pH}$ effect. For higher $\mathrm{pH}$ values, desorption was very low and limited to $2-3 \%$, which reflects the establishment of strong chemical bonds between the basic dye and the raw clay in the adsorption. ${ }^{18}$

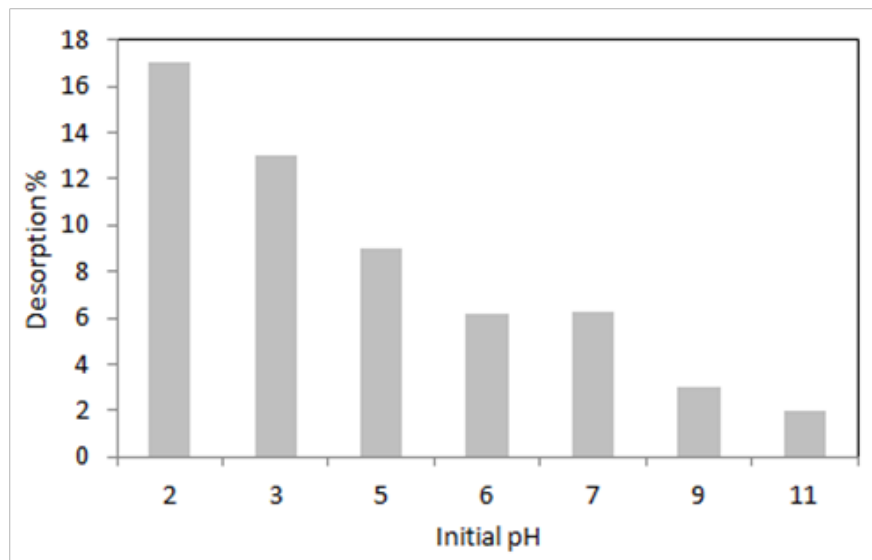

Figure 9 Desorption percentages from BY28-loaded AR as a function $\mathrm{pH}$ conditions.

\section{Adsorption mechanism of BY28 by AR}

The smectite can adsorbs cationic dye by different mechanisms: (i) exchange captions in the interlayer resulting from the interaction between dye and permanent negative charge and (ii) formation of internal sphere complexes by the silanol ( $\left.\mathrm{Si}^{-} \mathrm{O}^{-}\right)$and aluminol (Al-O-) groups of the clay. This mechanism is $\mathrm{pH}$-dependent charge (Figure 10)..$^{19,20}$

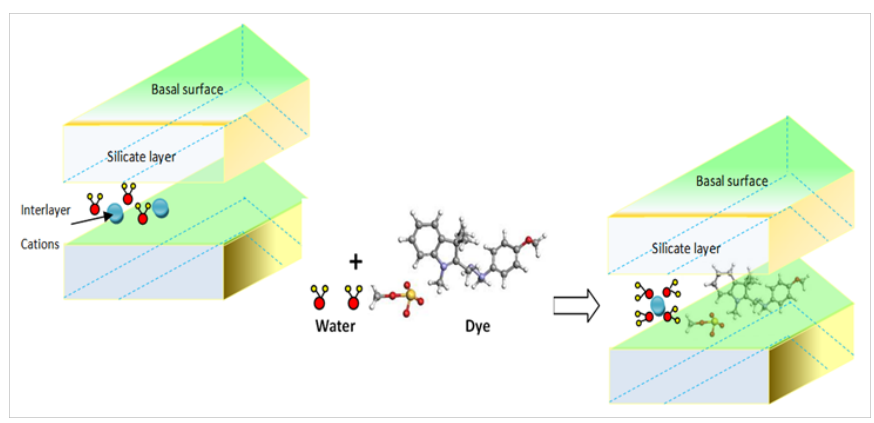

Figure 10 Schematic representation of adsorption mechanism of BY 28 by AR.

\section{Conclusion}

In summary, AR is found to be very effective in the removal of a basic dye from aqueous solution. Adsorption profile was highly $\mathrm{pH}$ dependent and was sought to be electrostatic in nature. The adsorption followed the second order kinetics with simultaneous occurrence of the intra particle diffusion of the dye. The adsorption obeyed to the Langmuir and Freundlich isotherms. The adsorption was spontaneous in nature.

\section{Acknowledgements}

None. 


\section{Conflict of interest}

The authors declare that there is no conflict of interest.

\section{References}

1. Citeve S. Estudo das dificuldades das empresas do setor têxtile vestuário no cumprimento da legislação ambiental, Centro Tecnológico das Indústrias Têxtile do Vestuário de Portugal, Portugal ; 2012.

2. Gupta VK, Carrott PJM, Ribeiro Carrott MML, et al. Low-cost adsorbents: growing approach to wastewater treatment-a review. Crit Rev Environ Sci Technol. 2009;39(10):783-842.

3. Rauf N, Tahir SS, Kang JH, et al. Equilibrium, thermodynamics and kinetics studies for the removal of alpha and beta endosulfan by adsorption onto bentonite clay. Chemical engineering journal. 2012;192:369-376.

4. Camarero S, Ibarra D, Martínez MJ, et al. Lignin-derived compounds as efficient laccase mediators for decolorization of different types of recalcitrant dyes. 2005;71(4):1775-1784.

5. Crini G Non-conventional low-cost adsorbents for dye removal: a review. Bioresource Technology. 97(9): 1061-1085

6. Beaulieu J. Identification géotechnique des matériaux argileux naturels par la mesure de leur surface au moyen du bleu de méthylène. Thèse 3ème cycle, Univ Orsay, India; 1979. p. 180.

7. Bergaya F, Vayer M. CEC of clays: measurement by adsorption of a copper ethylenediamine complex. Appl Clay Sci. 1997;12(3):275-280.

8. Wan Ngah WS, Hanafiah MA. Removal of heavy metal ions from wastewater by chemically modified plant wastes as adsorbents: a review. Bioresour Technol. 2008;99(10):3935-3948.

9. Caillère S, Henin S, Rautureau M. Minéralogie des argiles. Masson, Tunisia; 1982;1(2):1-2.
10. Safa Y, Bhatti, HN. Kinetic and thermodynamic modeling for the removal of Direct Red-31 and Direct Orange-26 dyes from aqueous solutions by rice husk. Desalination. 2011;272:313-322.

11. Langmuir I. The constitution and fundamental properties of solids and liquids. J Am Chem Soc. 1916;39(9):2221-2295.

12. Baliti J, Asnaoui A, Abouarnadasse S. L'élimination du bleu de methylene par une argile naturelle de Taza en milieu aqueux. International Journal of Innovative Researchin Advanced Engineering. 2014;1(6):2349-2163.

13. Djebbar M. Argile de Maghnia: purification et adsorption de pollutant. These de Doctorat en-sciences. 2014. p.192.

14. Lagergren S. Zur theorie der sogenannten adsorption geloester stoffe. Kungliga Svenska Vetenskapsakademiens, Handlingar. 1898;24(4):1-39.

15. Mckay G, Otterburn MS, Sweeney AG. The removal of colour from effluent using various adsorbents. IV. Silica. Equilibria and column studies. Water Research. 1980;14(1):21-27.

16. Weber WJ, Morriss JC. Kinetics of adsorption on carbon from solution. $J$ St Eng Div. 1963;89(2):31-60.

17. Faust SD, Aly OM. Adsorption processes for water treatment. Clean Soil Air water. 1988;16:572.

18. Dos Santos P, Girotto M, Levin Y. Simulations of Polyelectrolyte Adsorption to a Dielectric Like-Charged Surface. J Phys Chem B. 2016;39:10387-10393.

19. Freundlich HMF. Over the adsorption in solution. Z Phys Chem. 1906;57:385-471.

20. McKay G, Ho YS. Pseudo-second order model for sorption processes. Process Biochem. 1999;34(5):451-465. 